\title{
Studi Literatur Implementasi Sertifikasi Halal Produk UMKM
}

\author{
Fuadi $^{1 *}$, Andri Soemitra ${ }^{2}$, Zuhrinal M. Nawawi ${ }^{3}$ \\ ${ }^{1 *}$ Fakultas Ekonomi dan Bisnis, Universitas Malikussaleh, Kota Lhokseumawe, \\ Provinsi Aceh, Indonesia. \\ 2,3 Fakultas Ekonomi dan Bisnis Islam, Universitas Islam Negeri Sumatera \\ Utara Medan, Kabupaten Deli Serdang, Provinsi Sumatera Utara, Indonesia.
}

\begin{abstract}
Abstrak. Penelitian ini bertujuan untuk menganalisis penerapan jaminan produk halal pada UMKM di Indonesia. Data yang digunakan dalam analisis yang berkaitan dengan topik penelitian diambil dari berbagai literatur, baik dari buku maupun artikel jurnal. Data dari berbagai sumber kemudian dianalisis dengan menggunakan pendekatan literature review. Berdasarkan analisis, ditemukan babwa sektor makanan halal saat ini merupakan peluang baru untuk meningkatkan pertumbuban dan perkembangan ekonomi. Dikatakan peluang baru karena tidak hanya negara-negara mayoritas Muslim tetapi negara-negara minoritas Muslim juga mengambil bagian dalam pengembangan industri halal. Oleh karena itu, pemerintah Indonesia juga berupaya mengembangkan industri makanan dan minuman halal dalam negeri untuk mendorong pertumbuban industri halal. Dalam mendorong penerapan standar halal dimana salah satu hal yang diperlukan adalah sertifikasi halal, dikeluarkan Undang-Undang Nomor 33 Tabun 2014 tentang Jaminan Produk. Halal, Pasal 4 menyatakan bahwa sertifikasi produk halal adalah wajib. Metode yang digunakan dalam penelitian ini adalah penelitian kepustakaan. Studi literatur dalam penelitian ini dilakukan untuk mempelajari definisi kata kunci, memperdalam teori dan konsep serta mengidentifikasi variabel-variabel yang terkait dengan latar belakang dan konteks penelitian. Studi literatur terkait analisis hambatan produk halal, jurnal menggunakan aplikasi pencarian atau search application yang dicari di Google Scholar dengan kata kunci "Halal Product" jumlah hasil maksimal 20 dan kategori tahun sepanjang tahun (0 -0) Ada delapan artikel jurnal. Berikut rincian hasil pencarian jurnal menggunakan aplikasi publish and perish dan pencarian di Emerald Publishing. Pencarian melalui aplikasi publish and perish di Google Scholar dengan kata kunci inovasi produk bank syariah: 4 makalah. Emerald Publishing di Emerald Insight, dengan judul: Sertifikasi Halal: 6 makalah.
\end{abstract}

Kata kunci: Sertifikasi Halal; Produk Halal; UMKM.

\begin{abstract}
This study aims to analyze the implementation of halal product guarantees on MSMEs in Indonesia. The data used in the analysis related to the research topic were taken from various literature, both from books and journal articles. Data from various sources were then analyzed using a literature review approach. Based on the analysis, it was found that the halal food sector is currently a new opportunity to increase growth and economic development. It is said to be a new opportunity because not only Muslim-majority countries but Muslim-minority countries also take part in the development of the halal industry. Therefore, the Indonesian government is also trying to develop the domestic halal food and beverage industry to encourage the growth of the halal industry. In promoting the application of halal standards where one of the things needed is halal certification, Law Number 33 of 2014 concerning Halal Product Guarantee is issued, Article 4 states that halal product certification is mandatory. The method used in this research is library research. The literature study in this research was conducted to study the definition of keywords, to deepen theories and concepts, and to identify variables related to the background and context of the research. Literature studies related to the analysis of barriers to halal product, the journal uses a search application or search application that is searched on Google Scholar with the keyword "Halal Product" the maximum number of results is 20 and the year category is all year (0-0) There are eight journal articles. The following are the details of the journal search results using the publish and perish application and the search on Emerald Publishing. Search through the publish and perish application on Google Scholar with the keywords Islamic bank product innovation: 4 papers. Emerald Publishing on Emerald Insight, with the title: Halal Certification: 6 papers.
\end{abstract}

Keywords: Halal Certification; Halal Products; MSME.

*Author. Email: fuadi.msm@unimal.ac.id ${ }^{1}$, andrisoemitra@uinsu.ac.id ${ }^{2}$, zuhrinal.nawawi@uinsu.ac.id ${ }^{3}$

DOI: https://doi.org/10.35870/emt.v6i1.540

Received: 3 January 2022, Revision: 5 February 2022, Accepted: 8 February 2022, Available Online: 12 February 2022.

Print ISSN: 2579-7972; Online ISSN: 2549-6204.

Copyright@ 2022. Published by Lembaga Otonom Lembaga Informasi dan Riset Indonesia (KITA INFO dan RISET).

118 | Jurnal Ekonomi dan Manajemen Teknologi Vol. 6 | No. 1 | 2022 


\section{Pendahuluan}

Beberapa tahun terakhir industri halal menjadi trend dibeberapa negara termasuk Indonesia. Indonesia sebagai negara dengan penduduk padat yang mayoritas beragama Islam, maka perlu adanya perhatian terhadap produk makanan yang beredar bebas, yaitu tidak hanya memperhatikan dari sisi komposisi yang menawarkan kesehatan secara medis saja, namun juga perlu diperhatikan bahwa makanan tersebut halal untuk dikonsumsi.

Sektor makanan halal saat ini menjadi peluang baru untuk meningkatkan pertumbuhan dan pembangunan ekonomi. Dikatakan sebagai peluang baru sebab tidak hanya negara-negara dengan mayoritas muslim akan tetapi negara minoritas muslim pun turut ambil bagian dalam perkembangan industri halal. Oleh karenanya pemerintah Indonesia juga berupayamengembangkan industri makanan dan minuman halal dalam negeri untuk mendorong pertumbuhan industri halal. Perlu pemahaman mendalam tentang dunia industri halal, hal tersebut dapat tercerahkan dengan memahami bagaimana implementasi sertifikasi dan jaminan produk halal terlebih dahulu.

Di dunia, makanan halal berkembang pesat karena tidak hanya umat Islam yang tergiur dengan makanan halal tetapi juga non-Muslim karena makanan halal dijamin dari segi kebersihan dan kesehatannya. Serbuan pangan impor cukup menjadi tantangan apalagi Indonesia merupakan negara yang mayoritas penduduknya beragama Islam, negara-negara lain akan berlomba-lomba untuk meraih konsumen guna meraih keuntungan perusahaannya (Peristiwo, 2019)

Dalam mempercepat penerapan standar halal dimana salah satu yang dibutuhkan adalah sertfifikasi halal maka dikeluarkanlah undang undang untuk mendukung pemberlakuan standart halal. Berdasarkan Undang-Undang Nomor 33 Tahun 2014 tentang Jaminan Produk Halal, Pasal 4 menyebutkan sertifikasi halal produk adalah bersifat wajib. Ketentuan wajib bersertifikat halal bagi pelaku usaha yang memproduksi pangan atau memasukkan pangan ke Indonesia untuk diperdagangkan hendaklah menyatakan bahwa pangan yang bersangkutan halal bagi umat Islam. Penjelasan UndangUndang Jaminan Produk Halal menyatakan bahwa keterangan halal untuk suatu produk sangat penting bagi masyarakat Indonesia yang mayoritas memeluk agama Islam. Jaminan penyelenggaraan produk halal juga bertujuan memberikan kenyamanan, keamanan, keselamatan dan kepastian ketersediaan produk halal bagi masyarakat dalam mengkonsumsi dan menggunakan produk (Zuhairi, 2016).

Penelitian Rasyid, (2019) tentang "Dinamika Pelaksanaan Sertifikasi Halal Pada Produk Makanan dan Minuman Di Kota Medan, Sibolga dan Padangsidimpuan" menunjukkan bahwa, setiap elemen terkait kehalalan produk makanan dan minuman ditemukan berbagai permasalahan yang menghambat pelaksanaan sertifikasi halal, yaitu: keterbatasan kewenangan dan pendanaan kepada MUI (LP-POM) untuk melakukan sosialisasi sertifikasi halal, kurangnya kesadaran hukum produsen terkait dengan kehalalan produk makanan dan minuman. persyaratan sertifikasi halal pada produk, dan lemahnya pemahaman masyarakat muslim tentang perlunya memperhatikan kehalalan produk makanan dan minuman yang dikonsumsi.

Penelitian Debbi, (2018) tentang "Implementasi Sertifikasi Halal Pada Produk Pangan Di Kota Bengkulu" juga menunjukkan bahwa, sertifikasi halal pada produk pangan di Kota Bengkulu masih dilakukan oleh sebagian kecil jumlah Usaha Kecil Menengah (UKM). Hal itu dikarenakan minimnya informasi dan pengetahuan tentang sertifikasi halal. Penelitian (Maryati et al., 2016) tentang "Analisis Faktor Kendala Dalam Pengajuan Sertifikat Halal. (Studi Kasus: Pelaku Usaha Mikro, Kecil dan Menengah Makanan Beku di Jabodetabek) "juga menunjukkan, 60\% UKM makanan beku di Jabodetabek belum memiliki sertifikasi halal.

Data Badan Pusat Statistik juga menunjukkan jumlah UKM di Indonesia sebanyak 57 juta, namun yang sudah memiliki sertifikat halal masih sangat sedikit. Menurut data dari Indonesiaulama Dewan, sebagai lembaga yang berwenang menerbitkan sertifikasi halal, pada periode 20142015 telah menerbitkan sertifikat halal nasional untuk 6.231 perusahaan dan UKM (Waharini dan Purwantini: 2018). Artinya, masih ada jutaan UKM yang belum menerapkan sertifikasi halal. 
Kondisi di atas, menjadi kendala untuk meningkatkan daya saing dan perkembangan UKM di Indonesia. Padahal UKM memiliki peran yang sangat penting bagi pembangunan ekonomi di Indonesia, dimana UKM dapat memberikan kontribusi terhadap PDB dengan harga konstan sebesar 57,6\% (Sari, et al., 2015; Paju, 2016; Maryati, Syarief, dan Hasbullah, 2016; Viverita, Kusumastuti, dan Rachmawati, 2017). Menurut Nooh, dkk (2007) sertifikasi halal untuk produk UKM telah menjadi permintaan konsumen dan merupakan faktor penting yang menentukan keputusan pembelian konsumen. Prabowo, dkk (2015) menegaskan bahwa label halal menjadi salah satu faktor konsumen muslim sebelum melakukan keputusan pembelian.

Menurut Pasal 3 Undang-Undang Nomor 33 Tahun 2014 tentang Jaminan Produk Halal, bahwa penyelenggaraan jaminan produk halal bertujuan untuk memberikan kenyamanan, keamanan, keselamatan, dan kepastian ketersediaan Produk Halal bagi masyarakat dalam mengkonsumsi dan menggunakan Produk; dan meningkatkan nilai tambah bagi Pelaku Usaha untuk memproduksi dan menjual Produk Halal. Oleh karena itu, jaminan kehalalan produk berupa sertifikat halal merupakan kewajiban bagi pelaku usaha, termasuk UKM sebagai daya tawar dalam menjual produk halal, dan mengembangkan usaha (Afifi, 2014; Syafrida, 2016; Hidayat dan Siradj, 2015: 206).

Untuk mendukung perkembangan dari industri halal itu sendiri, sebab tidak banyak studi mengenai upaya bagaimana penerapan produk halal di tiap tiap daerah di Indonesia maka bisa dimulai dari implementasi sertifikasi halal pada produk makanan dan minuman UMKM.

\section{Tinjauan Literatur}

\section{Sertifikasi Halal dan Jaminan Produk Halal}

Sertifikasi halal merupakan sertifikasi halal yang dikeluarkan oleh Lembaga Pengkajian Pangan, Obat-obatan dan Kosmetika (LPPOM-MUI) yang menyatakan suatu produk sudah sesuai dengan syariat islam. Sertifikat halal ini dapat digunakan pembuatan label halal. Undangundang No. 33 Tahun 2014 tentang Jaminan
Produk Halal berusaha menyelesaikan kehawatiran masyarakat dengan memberikan aturan yang jelas mengenai penerbitan sertifikat halal. Sertifikat Halal itu sendiri merupakan sebagai bentuk pengakuan kehalalan suatu produk yang dikeluarkan oleh BPJPH berdasarkan fatwa halal tertulis yang dikeluarkan oleh MUI.

Sedangkan label halal adalah tanda kehalalan suatu produk. Pelaku Usaha yang telah memperoleh sertifikat halal wajib mencantumkan label halal pada produknya sesuai bentuk label halal yang berlaku nasional. Sertifikasi halal memiliki banyak sekali manfaat bagi konsumen salah satunya adalah untuk memberikan ketenangan terhadap produk yang dikonsumsi dapat terjamin dan aman. Hal ini tentu menjadi tujuan seluruh konsumen. Apalagi konsumen Muslim yang mana diperintahkan oleh Allah agar mengkonsumsi produk halalan thoyiban. Bagi produsen, sertifikasi halal memiliki dampak pada pemenangan pasar dalam pasar global karena produk tersebut memiliki nilai tambah sebagai salah satu cara untuk bersaing dengan berbagai competitor yang ada. Kepercayaan konsumen akan lebih mudah didapat bilamana produk yang memiliki sertifikasi halal, sebab tentulah produk yang sudah bersertifikasi halal merupakan produk yang aman dan terjamin.

Berikut beberapa regulasi yang mengatur mengenai produk halal yang ada di Indonesia antara lain (MUI, 2021):

1. (UU) No. 33 Tahun 2014 tentang Jaminan Produk Halal.

2. Pemerintah (PP) No. 31 Tahun 2019 tentang Peraturan Pelaksanaan UU No. 33 Tahun 2014 (UU JPH).

3. Peraturan Menteri Agama No. 26 Tahun 2019 tentang Penyelenggaraan Jaminan Produk Halal.

4. Keputusan Menteri Agama (KMA) No. 982 Tahun 2019 tentang Layanan Sertifikasi Halal.

5. Peraturan Pemerintah (PP) No. 39 Tahun 2021 tentang Penyelenggaraan Bidang Jaminan Produk Halal.

Sertifikasi halal melibatkan 3 pihak, yaitu BPJPH, LPPOM MUI sebagai lembaga pemeriksa halal 
(LPH), dan MUI. BPJPH melaksanakan penyelenggaraan jaminan produk halal. LPPOM MUI melakukan pemeriksaan kecukupan dokumen, penjadwalan audit, pelaksanaan audit, pelaksanaan rapat auditor, penerbitan audit memorandum, penyampaian berita acara hasil audit pada rapat Komisi Fatwa MUI. MUI melalui Komisi Fatwa menetapkan kehalalan produk berdasarkan hasil audit dan menerbitkan Ketetapan Halal MUI (MUI, 2021).

\section{Usaha Mikro Kecil dan Menengah (UMKM)}

Usaha mikro, kecil dan menengah yang selanjutnya disingkat menjadi UMKM adalah suatu bentuk usaha produktif yang dimiliki oleh perorangan atau badan usaha yang biasanya bergerak dalam ruang lingkup kegiatan perdagangan yang memiliki ciri atau karakteristik yang berbeda beda.

UMKM merupakan salah satu kelompok pelaku ekonomi terbesar dalam perekonomian Indonesia. Selain menjadi sektor usaha yang paling besar kontribusinya terhadap pembangunan ekonomi nasional, juga sebagaitempat menciptakan peluang kerja yang cukup besar bagi tenaga kerja dalam negeri, sehingga pengurangan pengangguran terbantu. Menurut PP No. 7 tahun 2021 UMKM dapat diklasifikasikan menurut kriteria modal usaha dan hasil penjualan tahunan. Modal usaha yakni modal sendiri sedangkan modal pinjaman untuk melakukan aktivitas usaha.

Berikut ini klasifikasi UMKM menurut kriteria kekayaan atau modal usaha berdasarkan pasal 35 ayat (3) PP No. 7 tahun 2021, antara lain sebagai berikut:

1. Usaha Mikro

Dalam usaha mikro modal usaha yang dimiliki tidak lebih atau paling banyak sejumlah 1 miliar rupiah, tidak termasuk tanah dan bangunan tempat usaha.

\section{Usaha Kecil}

Dalam usaha kecil modal usaha yang ada lebih dari 1-5 miliar rupiah, tidak termasuk tanah dan bangunan tempatusaha.

3. Usaha Menengah.

Dalam untuk usaha menengah yakni mempunyai modal usaha $5-10$ miliar rupiah, juga tidak termasuk tanah dan bangunan tempat usaha. Selain itu juga terdapat kriteria lain jika tidak memakai kriteria modal usaha.

Kriteria yang dimaksud adalah berdasar hasil penjualan tahunan sebagimana dalam pasal 35 ayat (6) PP No.7 tahun 2021 antara lain:

1. Usaha Mikro

Hasil penjualan tahunan yang dimiliki usaha mikro adalah paling banyak 2 miliar rupiah.

2. Usaha Kecil

Hasil penjualan yang dimiliki oleh usaha kecil paling sedikitnya $2-15$ miliar rupiah.

3. Usaha Menengah

Hasil penjualan dari usaha menengah ada pada kisaran 15 -50 miliar rupiah. Dengan daya serap tenaga kerja yang cukup tinggi, UMKM terbilang memiliki peran besar dalam pembangunan ekonomi. Oleh karenanya pemerintah menaruh perhatian cukup besar dalam membantu pengembangan UMKM.

\section{Metodologi Penelitian}

Metode yang digunakan dalam penelitian ini adalah studi literature review kepustakaan. Studi literatur dalam penelitian ini dilakukan untuk mempelajari definisi kata kunci, memperdalam teori dan konsep serta mengidentifikasi variabelvariabel yang terkait dengan latar belakang dan konteks penelitian (Petticrew \& Roberts, 2008). Studi literatur yang berkenaan dengan analisis implementasi jaminan produk halal melalui sertifikasi halal, pencarian jurnal menggunakan aplikasi publish or perish pencarian pada google scholar dengan keywords "produk halal umkm" maximum number of results 20 dan tahun kategori semua tahun (0-0) terdapat delapan artikel juranal. Berikut rincian hasil pencarian jurnal menggunakan aplikasi publish and perish dan pencarian pada Emerald Publishing. Penelusuran melalui aplikasi publish and perish pada google scholar dengan keywords produk halal umkm: 4 paper. Emerald Publishing on Emerald Insight, dengan title words: Halal Certification, Halal Products, MSME: 6 papers. 


\section{Hasil dan Pembahasan}

\section{Literature review Publish and Perish}

Penelusuran Literature review dengan menggunakan aplikasi publish and perish pada google scholar dengan keywords "produk halal UMKM" terdapat 4 paper terkait judul "Studi Literatur Implementasi Jaminan Produk Halal Melalui Sertifikasi Halal Pada Pelaku UMKM". Artikel yang terkait sebagai berikut:

Tabel 1. Literature review dengan publish and perish

\begin{tabular}{|c|c|c|}
\hline No. & Articles & Year \\
\hline 1 & $\begin{array}{l}\text { Arifin, (2020). Legal Analysis of Halal } \\
\text { Product Guarantee for Development of } \\
\text { Small and Medium Enterprises (SMEs) } \\
\text { Business in Indonesia. JURNAL } \\
\text { HUKUM ISLAM. }\end{array}$ & 2020 \\
\hline 2 & $\begin{array}{l}\text { Novitasari (2019) Novitasari, M. (2019) } \\
\text { Optimalisasi Potensi Perbankan Syariah } \\
\text { di Indonesia Bagi UMKM Halal Dalam } \\
\text { Mendukung Sustainable Development } \\
\text { Goals. Majalah Ekonomi. }\end{array}$ & 2019 \\
\hline 3 & $\begin{array}{l}\text { Pujiono et al., (2018) Strategi } \\
\text { Pengembangan Umkm Halal Di Jawa } \\
\text { Tengah Dalam Menghadapi Persaingan } \\
\text { Global. Indonesia Journal of Halal, 1(1), } \\
\text { 1. }\end{array}$ & 2018 \\
\hline 4 & $\begin{array}{l}\text { Mufidah et al., (2021) Model } \\
\text { Pengembangan Industri Halal Food di } \\
\text { Indonesia. smartlib.umri.ac.id. }\end{array}$ & 2018 \\
\hline
\end{tabular}

\section{Literature review Emerald Publishing}

Melalui penelusuran literature review pada Emerald Publishing terkait judul "Studi Literatur Implementasi Jaminan Produk Halal Melalui Sertifikasi Halal Pada Pelaku UMKM" dengan kata kunci "Halal Certification, Halal Products, MSME" didapati enam artikel yang terkait antara lain sebagai berikut:

Tabel 2. Literature review artikel Emerald Publishing

\begin{tabular}{llr}
\hline No. & \multicolumn{1}{c}{ Articles } & Year \\
\hline 1. & Kamarulzaman et al., (2021)"An 2021 \\
& investigation of adoption intention \\
& of halal traceability system among \\
& food SMEs", Journal of Islamic \\
& Marketing, Vol. ahead-of-print No. \\
& ahead-of-print. \\
& https://doi.org/10.1108/JIMA-11- \\
& 2020-0349 \\
& Jose \& Shanmugam, (2020), 2020 \\
& "Supply chain issues in SME food \\
& sector: a systematic review", Journal \\
& of Advances in Management \\
& Research, Vol. 17 No. 1, pp. 19-65. \\
& https://doi.org/10.1108/JAMR-
\end{tabular}

02-2019-0010

3. Namagembe et al., (2016), "Green supply chain management practice adoption in Ugandan SME manufacturing firms: The role of enviropreneurial orientation", World Journal of Science, Technology and Sustainable Development, Vol. 13 No. 3, pp. 154-173.

https://doi.org/10.1108/WJSTSD -01-2016-0003

4. Bashir et al., (2019), "Strategies for improving the competitiveness of Korean seafood companies in the overseas halal food market", Journal of Islamic Marketing, Vol. 10 No. 2, pp. 606-632. https://doi.org/10.1108/JIMA-032018-0056

5. Rios et al., (2014), "Do halal certification country of origin and brand name familiarity matter?", Asia Pacific Journal of Marketing and Logistics, Vol. 26 No. 5, pp. 665-686.

https://doi.org/10.1108/APJML03-2014-0046

6 Muneeza \& Mustapha, (2020), "Halal certification process for fisheries products in Maldives", Journal of Islamic Marketing, Vol. 12 No. 2, pp. 451-466 https://doi.org/10.1108/JIMA-022019-0035

\section{Pembahasan}

Indonesia sebagai negara berpenduduk muslim terbesar memiliki peluang pasar yang potensial bagi konsumsi produk pangan, obat-obatan dan kosmetika bagi pelaku usaha dalam negeri sendiri maupun dari luar negeri (Fathimah, 2017). Selama beberapa dekade terakhir, pasar religi telah memasuki fase baru yang ditandai dengan bentuk regulasi, sertifikasi, dan standardisasi baru dalam skala global. Indonesia terdiri dari sekitar 240 juta penduduk (BPS, 2010) dan 87\% penduduknya beragama Islam (Fischer, 2016).

Dengan jumlah penduduk muslim yang sangat besar, Indonesia merupakan pasar yang potensial bagihalal produk (Fatmasari Sukesti \& Mamdukh Budiman, 2014). Indonesia juga berpotensi untuk tidak hanya menjadi pasar utama tetapi juga produsen utama halal produk (S Soesilowati, 2018). 
Saat ini, Indonesia telah memasuki era Global Value Chain. Salah satu hal penting di era Global Value Chain yang perlu diupayakan adalah penjaminan halal dari bahan baku yang digunakan dalam setiap proses produksi. Hal ini disebabkan oleh beberapa alasan, yaitu: pertama, Penduduk Indonesia yang mayoritas beragama Islam dan ini bisa menjadi pasar yang potensial. Kedua, kesadaran beragama masyarakat muslim di Indonesia semakin baik, sehingga dalam produk konsumen khususnya makanan dan minuman memerlukan legalisasi berupa halal jaminan produk. Ketiga, Indonesia memiliki banyak UKM yang berperan penting dalam menggerakkan roda perekonomian Indonesia.

Merujuk pada data Kementerian Koperasi dan Usaha Kecil Menengah (2013), jumlah usaha mikro mencapai 98,79\% sedangkan jumlah usaha kecil hanya $1,11 \%$, dan jumlah usaha menengah memiliki persentase terendah dengan 0,09\%. Dari data tersebut, tidak satupun dari mereka yang memiliki kemampuan untuk menjamin produk mereka halal. Keempat, konsumen yang bukan muslim menganggap bahwa setiap halal produk dengan kualitas tinggi yang aman dan higienis. Kelima, peran norma dan agama dianggap sebagai factor penentu terlaksananyahalal jaminan produk.

Namun, tidak semua pengusaha benar-benar bisa mendapatkanhalal penjaminan produk khususnya UKM karena beberapa alasan: kurangnya pendampingan, kurangnya sosialisasi, persyaratan yang rumit dan lain-lain. Oleh karena itu, pemerintah sebagai lembaga tertinggi yang bertanggung jawab atas keberlangsungan UKM di Indonesia harus memberikan pendampingan dan kemudahan bagi UKM untuk memperolehnya halal jaminan produk.

Pemerintah dapat bekerja sama dengan halal Lembaga Sertifikasi baik di dalam maupun di luar negeri. Saat ini, ada tiga belas negara di Asia yang sangat peduli denganhalal label dan validitas sertifikasinya telah diakui oleh LPPOM MUI yaitu Singapura, Malaysia, Brunei Darussalam, Jepang, Taiwan, India, Hong Kong, Thailand, Filipina, Vietnam, Sri Lanka. Jika ada produk yang beredar secara internasional khususnya di Asia, maka wajib mencantumkan tiga belashalal logo dari beberapa negara yang berbeda. Ini memberikan berbagai halal logo yang saat ini menjadi tantangan utama bagi halal industri di Indonesia khususnya UKM.

Pemerintah Indonesia melalui LPPOM-MUI menetapkan beberapa persyaratan: dalam proses melamar halal sertifikat, Pengusaha harus memahami persyaratan dan mengikuti halal pelatihan sistem penjaminan dan menerapkannya pada produk, Melengkapi beberapa dokumen, antara lain daftar produk, daftar bahan dan dokumen, matriks produk, halal manual sistem penjaminan, diagram alir proses, daftar alamat fasilitas produksi, bukti halal sosialisasi kebijakan, bukti pelatihan internal dan pendaftaran bukti audit internal halal sertifikasi Melakukan pemantauan pra audit dan pembayaran kontrak sertifikasi, Audit Pemantauan pasca audit memiliki izin edar untuk PIRT/MD dan memiliki izin edar MD untuk risiko tinggi produk.

\section{Kesimpulan}

Jaminan produk halal bagi UKM berupa sertifikat halal menjadi sangat penting karena dengan adanya sertifikasi halal, produk pangan yang menjadi konsumsi masyarakat telah mendapatkan legalitas dan perlindungan hukum dari pemerintah. Argumentasi pentingnya jaminan produk halal bagi UKM di Indonesia, yaitu:pertama, penduduk Indonesia yang mayoritas beragama Islam sehingga menjadi pasar yang potensial; kedua, kesadaran beragama umat Islam di Indonesia semakin baik, sehingga mengkonsumsi produk khususnya makanan dan minuman memerlukan legalisasi berupa jaminan produk halal; ketiga, Indonesia memiliki banyak UKM yang berperan penting dalam pembangunan ekonomi nasional; keempat, konsumen non-Muslim menganggap bahwa setiap produk halal berkualitas tinggi, aman dan higienis; kelima, peran norma agama dalam pelaksanaan jaminan produk halal. Namun pada kenyataannya tidak semua pengusaha dapat memperoleh jaminan kehalalan produk khususnya UKM karena beberapa alasan antara lain kurangnya pendampingan, kurangnya sosialisasi, persyaratan yang rumit dan lain-lain. 
Jaminan Produk Halal Bagi Pengembangan Usaha UKM telah diatur dalam UndangUndang Nomor 33 Tahun 2014 tentang Jaminan Produk Halal, yang mewajibkan semua produk makanan, minuman dan obatobatan yang beredar di Indonesia memiliki sertifikasi halal. Untuk pengembangan usaha UKM, $\mathrm{BPJPH}$ dengan instansi pemerintah yang menyelenggarakan urusan pemerintahan di lapangan koperasi, usaha mikro, kecil dan menengah juga melakukan sosialisasi dan pendampingan sertifikasi halal Produk. Namun penjaminan produk halal untuk pengembangan usaha UKM di Indonesia menemui beberapa kendala, yaitu: keterbatasan informasi awal jaminan produk halal, proses yang sangat rumit, dan biaya yang tinggi untuk proses sertifikasi produk halal. Oleh karena itu, pemerintah harus membantu dan memfasilitasi UKM untuk mendapatkan jaminan produk halal. Pemerintah juga harus memberikan regulasi dan tahapan yang jelas sebagai kepastian hukum bagi UKM dalam menjalankan usahanya, terutama terkait dengan jaminan kehalalan produk.

\section{Daftar Pustaka}

Arifin, R. (2020). Legal Analysis of Halal Product Guarantee for Development of Small and Medium Enterprises (SMEs) Business in Indonesia. JURNAL HUKUM ISLAM. http://ejournal.iainpekalongan.ac.id/index.php/j $\mathrm{hi} /$ article/view/2693

Bashir, K. M. I., Kim, J. S., Mohibbullah, M., Sohn, J. H., \& Choi, J. S. (2019). Strategies for improving the competitiveness of Korean seafood companies in the overseas halal food market. Journal of Islamic Marketing, 10(2), 606-632. https://doi.org/10.1108/JIMA-03-20180056.

Debbi, N. (2018). Implementasi Sertifikasi Halal Pada Produk Pangan. Qiyas, 3(1), 154 166.
Fathimah, E. (2017). Jaminan Produk Halal Bagi Perlindungan Konsumen Telaah RUUJPH (Rancangan Undang-Undang Jaminan Produk Halal) Dalam Perspektif Hukum Ekonomi Islam. Muamalah, 3(1), 73-86.

Fatmasari Sukesti, \& Mamdukh Budiman. (2014). the Influence Halal Label and Personal Religiousity on Purchase. International Journal of Business, Economics and Law, 4(1), 2012-2015.

Fischer, J. (2016). Markets, religion, regulation: Kosher, halal and Hindu vegetarianism in global perspective. Geoforum, 69, 67-70. https://doi.org/10.1016/j.geoforum.201 5.12.011

Jose, A., \& Shanmugam, P. V. (2020). Supply chain issues in SME food sector: a systematic review. Journal of Advances in Management Research, 17(1), 19-65. https://doi.org/10.1108/JAMR-02-20190010

Kamarulzaman, N. H., Muhamad, N. A., \& Mohd Nawi, N. (2021). An investigation of adoption intention of halal traceability system among food SMEs. Journal of Islamic Marketing. https://doi.org/10.1108/JIMA-11-20200349

Maryati, T., Syarief, R., \& Hasbullah, R. (2016). Analisis Faktor Kendala dalam PengajuanSertifikat Halal. (Studi Kasus: Pelaku Usaha Mikro, Kecil dan Menengah Makanan Beku diJabodetabek). Jurnal Ilmu Produksi Dan Teknologi Hasil Peternakan, 4(3), 364-371. https://doi.org/10.29244/jipthp.4.3.364371

Mufidah, A. N., Syafaq, H., \& Yudha, A. T. R. C. (2021). Integrated Economic Empowerment: Evidence in the Religious Area of Gusdur'S Tomb. Jurnal Ekonomi Syariah Teori Dan Terapan, 8(6), 785. https://doi.org/10.20473/vol8iss20216p p785-796 
Muneeza, A., \& Mustapha, Z. (2020). Halal certification process for fisheries products in Maldives. Journal of Islamic Marketing.

Namagembe, S., Sridharan, R., \& Ryan, S. (2016). Green supply chain management practice adoption in Ugandan SME manufacturing firms. World Journal of Science, Technology and Sustainable Development, 13(3), 154-173. https://doi.org/10.1108/wjstsd-012016-0003

Novitasari, M. (2019). Optimalisasi Potensi Perbankan Syariah di Indonesia Bagi UMKM Halal Dalam Mendukung Sustainable Development Goals. Majalah Ekonomi.

http://jurnal.unipasby.ac.id/index.php/ majalah_ekonomi/article/view/1902

Peristiwo, H. (2019). Indonesian Halal Food Industry: Development, Opportunities and Challenges on Halal Supply Chains. Journal of Islamic Studies and Humanities, 4(2), 218-245.

Petticrew, M., \& Roberts, H. (2008). Systematic Reviews in the Social Sciences: A Practical Guide. In Systematic Reviews in the Social Sciences: A Practical Guide. John Wiley \& Sons.

https://doi.org/10.1002/9780470754887
Pujiono, A., Setyawati, R., \& Idris, I. (2018). Strategi Pengembangan Umkm Halal Di Jawa Tengah Dalam Menghadapi Persaingan Global. Indonesia Journal of Halal, 1(1), 1. https://doi.org/10.14710/halal.v1i1.3109

Rasyid, A. (2019). Dinamika Pelaksanaan Sertifikasi Halal pada Produk Makanan dan Minuman Di Kota Medan, Sibolga dan Padangsidimpuan. MIQOT: Jurnal Ilmu-Ilmu Keislaman, 43(2), 167-201.

Rios, R. E., Riquelme, H. E., \& Abdelaziz, Y. (2014). Do halal certification country of origin and brand name familiarity matter? Asia Pacific Journal of Marketing and Logistics, 26(5), 665-686. https://doi.org/10.1108/APJML-032014-0046

S Soesilowati, E. (2018). Business opportunities for Halal Products in the Global Market: Muslim Consumer Behaviour and Halal food Consumption. Journal of Indonesian Social Sciences and Humanities, 3(1), 151-160. https://doi.org/10.14203/jissh.v3i1.50

Zuhairi, A. (2016). Hukum Perlindungan Konsumen \& Problematikanya. Sinar Grafika. 